\title{
Study on the Layout Planning and Optimization for an Electronic Product Workshop Based on Cell Manufacturing
}

\author{
Liao Shengchong ${ }^{1}, \mathrm{He} \mathrm{Wei}^{1}$ and Zhou Hongli ${ }^{2}$ \\ ${ }^{1}$ Aerospace Long March Launch Vehicle Technology CO.,LTD, Beijing100076, China \\ ${ }^{2}$ University of Science \& Technology Beijing, Beijing100083, China
}

Key Words: SLP, Cell manufacturing, Logistics analysis, Layout optimization

\begin{abstract}
Aiming at the characteristics of multi-variety and small batch production of electronic products, a workshop layout optimization method based on cell manufacturing is proposed. First, the original layout and its problems are analyzed. Then, product-quantity analysis is carried out, and the product families are classified. Aiming at the product families, logistic quantities, non-logistic quantities are calculated using systematic layout planning (SLP) method. Comprehensive correlation graph and position correlation graph of operating units are attained. Based on the relations of operation units, the workshop layout is optimized, and the optimizing results are analyzed from logistic and non-logistic aspects. Application results show that the method is feasible and effective, and the logistic and non-logistic indices are improved significantly after optimization.
\end{abstract}

\section{Introduction}

With the rapid development of the aviation industry, customers' demand continue to increase, mainly as product demand develop towards personalized, diversified and complicated direction, shortening product delivery cycle, resulting in an increasingly competitive market. In order to respond quickly to customers' demand of multi-variety, small batch production, short-cycle and effectively raise production efficiency, the role of workshop logistics planning and layout in manufacturing system has become increasingly prominent. After investigation, about $90 \%$ to $95 \%$ in the product production cycle for the logistics time, which accounts for about $30 \%-75 \%$ of the total cost of production, so logistics planning and layout of the workshop has become one of the effective means to improve production efficiency in recent years.

As the core of logistics planning and design, the main methods of workshop layout planning include mathematical model method, sample method, graphical method and Systematic Layout Planning method. Among them, mathematical model method can improve the accuracy of systematic layout, but difficult to solve complex problems. Sample method is suitable for relatively simple layout, but the accuracy is relatively poor. Although graphical method combines mathematical model method and sample method, but its operability is poor, and difficult to apply in practice. As the current main method of workshop logistics planning and layout, SLP effectively combines workshop production units with departments through systematic facility layout and optimization theory, reducing logistics path and handling waste, with the advantage of the efficient use of space, efficiency improvement and cost reduction, etc. .Because of the advantages of SLP, it is widely used in logistics planning and design of all industries, and obtained remarkable achievement. The survey found that, although SLP currently has made remarkable achievements in all industries, but its application is also less in aerospace electronic products production.

Despite a wide variety of aerospace electronics, the process route of all products is with the same or similar characteristics partly. Therefore, these products are very suitable for using cell manufacturing to solve the problem of low production efficiency and flexibility, which is mainly caused by multi-variety and small batch production. This paper combines SLP technology with production unit layout planning technology, to optimize layout in an electronic product workshop based on cell manufacturing. Firstly, the current product flow path, processing areas and it's problems are analyzed; secondly, the product of workshop are divided into production units, and logistic quantities, logistic intensity of relations are calculated using systematic layout planning 
(SLP) method. Comprehensive correlation graph and position correlation graph of operating units are attained. Finally, based on these above work, the workshop layout is optimized, and the optimizing results are analyzed from logistic and non-logistic aspects.

\section{Analysis of the current situation of workshop layout}

Workshop mainly produces sensor electronics, and the workshop production belongs to typical multi-varieties and small batch production mode because of a wide range of products, complex process, small batch, small volume, large span of batch changes. In recent years, with a substantial increase in the number of customers' demand, products further present Diversification, Personalization and small-amount. The current workshop production mode is that a production staff is responsible for the production of a batch of products. Due to the complexity of production process, lengthy logistics path, handling efficiency is very low, which has become a major factor restricting the productivity improvement.

Figure 1 shows the current operation units distribution. According to the function of each operation area, the current operation areas are divided into 15 operation units, such as high temperature assembly, high temperature sintering, low temperature calibration etc. The 15 operation units are located in different floors of the workshop, without taking the logistics relations between operation units into account when planning. The logistics path between main processes is long. Stream of parts and people are frequent, and it is followed with long handling distances and high frequency of handling times.

Table 1: Division table of operation units

\begin{tabular}{cc}
\hline Number of units & Name of operation areas \\
\hline 1 & high temperature assembly \\
2 & high temperature sintering \\
3 & low temperature Calibration \\
$\ldots \ldots .$. & $\ldots . .$. \\
15 & process room \\
\hline
\end{tabular}

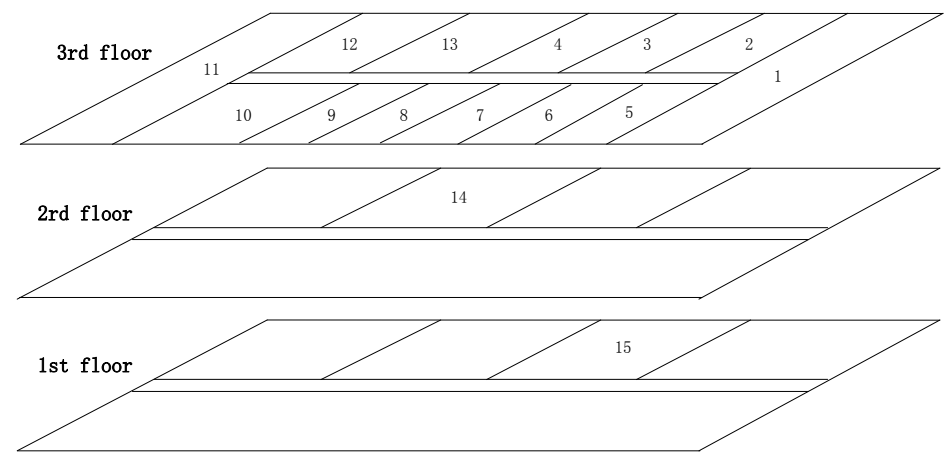

Fig.1: The current layout of production workshop

\section{The workshop layout based on SLP method}

The logistics relations of main product workshop produces between operation units are calculated by using SLP method and the layout of operation space is optimized, to achieve the purpose of guaranteeing production efficiency, sorting the flow of material or people, shortening the moving time, reducing handling or the amount of movement. However, the varieties of products in the electronic workshop are complex and process route are diversified, which brings great difficulties for the implementation of SLP. Further analyze the varieties and yield of the workshop and draw the P-Q (Product-Quantity) graph, which shows that $40 \%$ of varieties of products account 
for about $60 \%$ of the workshop production in spite of multi-variety and small batch production, and different types of products have a strong similarity in the process. Therefore, this paper proposes the cell manufacturing mode, dividing workshop's main products into 21 categories according to the similarity of the process, each category of products with the similar process and logistics route. On this basis, using SLP method to calculate the logistics relations can be based on product categories, greatly reducing calculation workload and improving the accuracy of analysis.

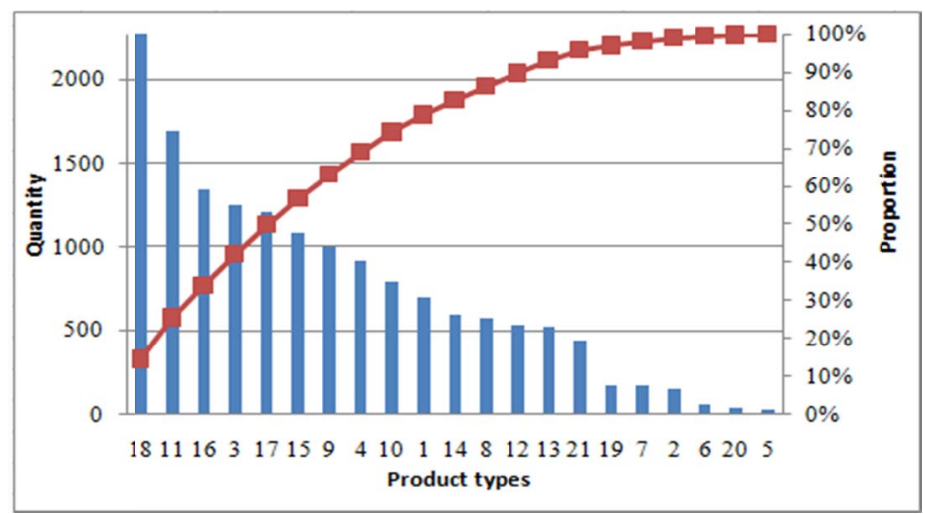

Fig. 2: Product-quantity analysis of products in workshop

\section{Logistics intensity calculation}

The calculation steps of logistics intensity are as follows: First, analyze the processing of 21 categories of products to determine their process routes, moving processes of product processing, the moving distance and quantities of production; Second, based on the production quantities and the moving distance, calculate the moving distance and work out the table of the material flow distance matrix for each type of product in different production areas; Third, work out the table of logistics matrix for each type of product according to the workshop layout and production quantities; Fourth, based on the above mentioned tables, compile the total logistic quantities matrix for each type of product and then based on this table, aggregate the logistics intensity for each type of product processing. Table 2 is the logistics intensity grading table based on SLP standards. Based on Table 2 and the above four calculation steps, the summary table of logistics intensity can be worked out as shown in Table 3. The operating units which do not appear in Table 3 have no fixed logistics, so the intensity level is $\mathrm{U}$ grade.

Table 2: Division table of logistics intensity grading

\begin{tabular}{ccc}
\hline the level of logistics intensity & symbol & The proportion of logistics routes (\%) \\
\hline Very high logistics intensity & A & 10 \\
higher logistics intensity & E & 20 \\
Relatively high logistics intensity & I & 30 \\
General logistics intensity & O & 40 \\
Negligible logistics intensity & U & 0 \\
\hline
\end{tabular}

Table 3: The summary table of logistics intensity

\begin{tabular}{cccccccc}
\hline $\begin{array}{c}\text { Sequence } \\
\text { number }\end{array}$ & $\begin{array}{c}\text { Pairs of } \\
\text { operation } \\
\text { units }\end{array}$ & $\begin{array}{c}\text { Logistics } \\
\text { intensity }\end{array}$ & $\begin{array}{c}\text { Logistics } \\
\text { intensity } \\
\text { grading }\end{array}$ & $\begin{array}{c}\text { sequence } \\
\text { number }\end{array}$ & $\begin{array}{c}\text { Pairs of } \\
\text { operation } \\
\text { units }\end{array}$ & $\begin{array}{c}\text { logistics } \\
\text { intensity }\end{array}$ & $\begin{array}{c}\text { logistics } \\
\text { intension } \\
\text { grading }\end{array}$ \\
\hline
\end{tabular}




\begin{tabular}{cccccccc}
1 & $2-1$ & 22304500 & $\mathrm{~A}$ & 8 & $14-5$ & 4852908 & $\mathrm{I}$ \\
2 & $2-15$ & 16059908 & $\mathrm{~A}$ & 9 & $1-15$ & 1001610 & $\mathrm{I}$ \\
3 & $10-5$ & 11842284 & $\mathrm{E}$ & 10 & $10-4$ & 791000 & $\mathrm{I}$ \\
4 & $10-2$ & 11389852 & $\mathrm{E}$ & 11 & $4-2$ & 717500 & $\mathrm{I}$ \\
5 & $14-2$ & 8893830 & $\mathrm{E}$ & 12 & $5-2$ & 470500 & $\mathrm{O}$ \\
6 & $14-6$ & 6146070 & $\mathrm{I}$ & 13 & $14-15$ & 428600 & $\mathrm{O}$ \\
7 & $14-10$ & 4863000 & $\mathrm{I}$ & 14 & $4-1$ & 182125 & $\mathrm{O}$ \\
\hline
\end{tabular}

Considering that there are various factors such as the continuity, material handling, public facilities, and personnel and so on during the workshop production process, the non-logistics relations should also be determined. After extensive researches, the non-logistics factors which influence the workshop mainly include the degree of the similarity of the operating property, temperature, noise, vibration, dust, the same group of employees working. Based on the non-logistics factors and their grades as shown in table 4, the workshop's non-logistic density grade can be worked out as shown in table 5 . The non-logistics density grade which do not appear in table 5 is $U$ grade.

Table 4: The reference table of the grading division on non-logistics affinity degree

\begin{tabular}{cccc}
\hline affinity degree & Letter & Reason code & Reason \\
\hline Absolutely necessary & $\mathrm{A}$ & 1 & The continuity of the work process \\
'articularly necessary & $\mathrm{E}$ & 2 & Close relation \\
Important & $\mathrm{I}$ & 3 & Separate arrangement \\
General & $\mathrm{U}$ & 4 & Using the same set of staff \\
unimportant & $\mathrm{O}$ & 5 & High temperature, vibration, dust \\
undesirable & $\mathrm{X}$ & 6 & \\
\hline
\end{tabular}

Table 5: The registration table of non-logistics density

\begin{tabular}{cccccc}
\hline $\begin{array}{c}\text { sequence } \\
\text { number }\end{array}$ & $\begin{array}{c}\text { Pairs of } \\
\text { operation } \\
\text { units }\end{array}$ & $\begin{array}{c}\text { Logistics } \\
\text { intensity } \\
\text { grading }\end{array}$ & $\begin{array}{c}\text { sequence } \\
\text { number }\end{array}$ & $\begin{array}{c}\text { Pairs of } \\
\text { operation } \\
\text { units }\end{array}$ & $\begin{array}{c}\text { Logistics } \\
\text { intensity } \\
\text { grading }\end{array}$ \\
\hline 1 & $2-1$ & A & 27 & $4-3$ & O \\
$\ldots \ldots$ & $\ldots \ldots$ & $\ldots \ldots$ & $\ldots \ldots$ & $\ldots \ldots$ & $\ldots \ldots$ \\
4 & $5-1$ & E & 12 & $5-15$ & I \\
$\ldots \ldots$ & $\ldots \ldots$ & $\ldots \ldots$ & $\ldots \ldots$ & $\ldots \ldots$ & $\ldots \ldots$ \\
21 & $11-8$ & I & 47 & $8-3$ & X \\
$\ldots \ldots$ & $\ldots \ldots$ & $\ldots \ldots$ & $\ldots \ldots$ & $\ldots \ldots$ & $\ldots \ldots$ \\
\hline
\end{tabular}

\section{Comprehensive Correlation Analysis}

The following is the calculating result based on the part 2.1. It takes a comprehensive consideration of the impact of the workshop's logistics and non-logistics activities on production and determines comprehensive correlation among different operating units and areas. The specific steps are as follows:

Step1: Determine the weight between logistics relations and non-logistics relations. It takes a comprehensive consideration of logistics and non-logistics relations and determines the importance of two relations. After in-depth analysis of the system, the workshop uses the single staff completed mode of production. Because logistic quantities is large and parts transfer between all production units, using logistics relations to determine operating position can effectively solve the problem; In addition, the workshop has special requirements on some non-logistics relations (such as high temperature equipment, spot welding etc.).Therefore, comprehensively consider the actual situation, using $2: 1$ as the weight between logistics and non-logistics relations. 
Step2: Quantify score and calculate comprehensive correlation. Calculate the score of Logistics intensity and non-logistics intensity according to $A=4 、 E=3 、 I=2 、 O=1 、 U=0, X=-1$ and work out comprehensive correlation between all operating units according to the weight between logistics and non-logistics relations.

Step3: Divide comprehensive mutual grading. According to grading table of comprehensive correlation, determine the level of comprehensive correlation in the workshop and draw the comprehensive correlation graph as shown in figure 3.

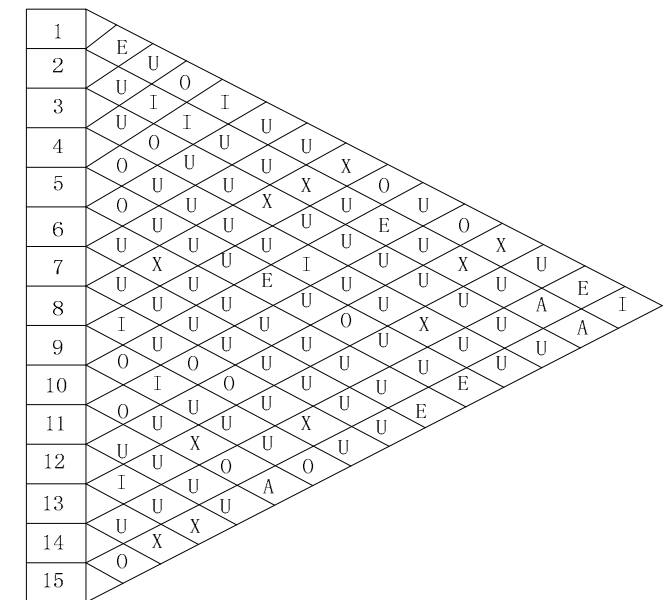

Fig.3:.Comprehensive correlation graph

\section{Determination of workshop operating position}

Drawing position correlation graph can be based on mutual relations between comprehensive operating units. Drawing principle is: operating units which get very high scores are arranged in the middle of graph, and then based on the scores, operating units are arranged sequentially in the graph. Operating units which score high have a priority of arrangement, working out position correlation graph of operating units as shown in figure 4.

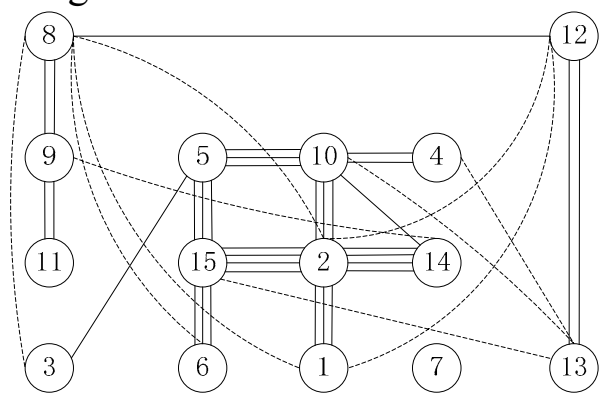

Fig.4: Position correlation graph of operating units

\section{The optimized scheme workshop layout}

\section{Workshop layout improvement}

Based on position correlation graph of the operation units, this paper conducts a local adjustment and optimization. Based on the characteristics of production mode, product types and batch in the workshop production unit, fully consider on the influence of existing space, high temperature and spot welding facilities on the environment. When adjust and optimize workshop layout, take into account factors as follows:

i) Special facilities. Because high temperature and noise in the production will have a certain impact on the sensitive products and components, Special facilities such as melt welding machine, spot welding machine and high temperature box (furnace)cannot be arranged in the same room. But the arrangement cannot be too far because some products and components must take operations 
such as high heating, spot welding after processing and assembling. Therefore, the layout of special facilities must be close to the core assembly room, so as to reduce logistics transfer distance between all rooms and share special equipment.

ii) Personnel arrangement. Avoid the staff to walk back and forth between different rooms in production units, which lead to crossover and confusion of personnel movement. The main process of all product families must be completed in the same production unit, and then transfer to other production units only when using special equipment, so priority should be given to $2-1,10-5$ and 10-2, 2-15.

iii) Regional division. Production areas and functional areas are mixed with each other in the original layout, but the two regional business intersection is less. Production areas and functional areas need to be separated without mutual interference when take measures for improvement.

Taking the above factors and existing workshop constraints into account and then adjusting the original production layout, workshop layout scheme are optimized as shown in Figure 5.
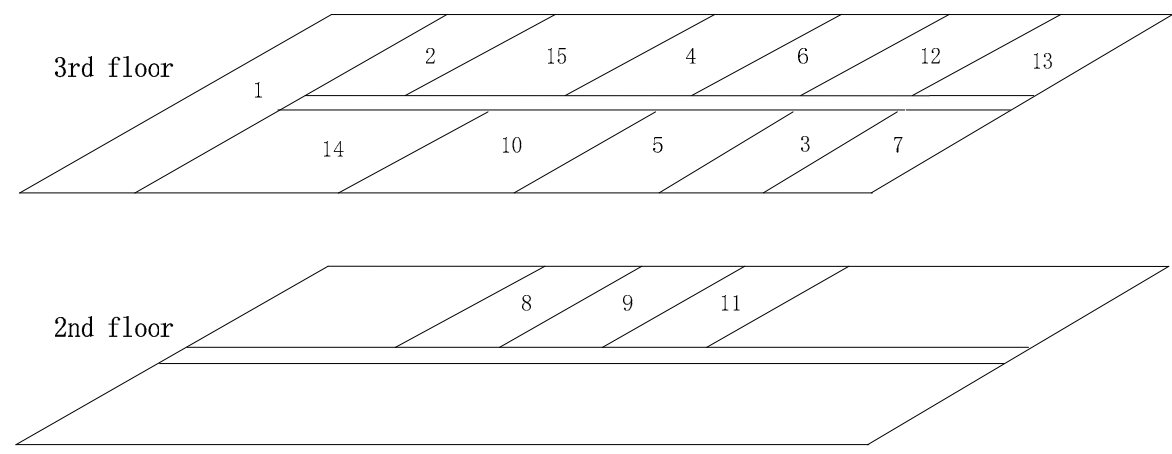

Fig.5: Optimization scheme of the production workshop layout

\section{Analysis of improvement effectiveness}

Apply the above improved scheme to the production workshop, and then compare and evaluate logistic indices such as handling amount, handling distance and logistics intensity; Select process flow, facilities sharing and site as non-logistic indicators, specific things as shown in table 6 and table 7. From Table 6 , the annual handling amount of logistics reduced $25.9 \%$ after improvement, and the annual total carrying distance of the material flow reduced $39.8 \%$. From Table 7 ,in the non-logistics indicators, logistic layout uses storehouse as its core and the production operation room is close to the storehouse. Logistics is smooth and orderly, so it can effectively reduce the logistic movement amount. Facility layout is reasonable, with a high degree of sharing. Each unit is close to the facility and work in process(WIP) are less in the tidy production site. Through the above analysis, the logistic and non-logistic indicators are promoted significantly after optimization. The layout of the improved scheme has obvious advantages.

Table 6: The comparison of logistics indices before and after improvement

\begin{tabular}{lccccc}
\hline \multirow{2}{*}{ Scheme } & \multicolumn{2}{c}{ Annual total handling amount } & \multicolumn{2}{c}{$\begin{array}{c}\text { Annual total handling } \\
\text { distance }\end{array}$} & $\begin{array}{c}\text { Handling } \\
\text { intensity }\end{array}$ \\
\cline { 2 - 4 } & Handling amount & saving & $\begin{array}{c}\text { Handling } \\
\text { distance }\end{array}$ & saving & high \\
$\begin{array}{c}\text { Before } \\
\text { improvement } \\
\text { After improvement }\end{array}$ & 2508698 & - & 79643687 & - & $\begin{array}{c}\text { Obvious } \\
\text { decrease }\end{array}$ \\
\hline
\end{tabular}

Table 7: The comparison and evaluation of non-logistics indices before and after improvement

Scheme Technological Process

Facilities sharing

On site 


\begin{tabular}{|c|c|c|c|}
\hline $\begin{array}{c}\text { Before } \\
\text { improvement }\end{array}$ & $\begin{array}{c}\text { The layout does not conform } \\
\text { to the process flow. } \\
\text { Roundabout processing } \\
\text { route. } \\
\text { High logistics intensity. }\end{array}$ & $\begin{array}{l}\text { The degree of facility } \\
\text { sharing is low. } \\
\text { The process route of } \\
\text { sectional production is } \\
\text { long. }\end{array}$ & $\begin{array}{c}\text { Much } \\
\text { accumulation } \\
\text { of WIP on } \\
\text { disorderly site. }\end{array}$ \\
\hline $\begin{array}{c}\text { After } \\
\text { improvement }\end{array}$ & $\begin{array}{l}\text { Operation units are high } \\
\text { correlated by using } \\
\text { storehouse as the core. } \\
\text { Smooth and orderly logistics, } \\
\text { low logistics intensity. }\end{array}$ & $\begin{array}{c}\text { Rational facilities layout. } \\
\text { High degree of sharing. } \\
\text { Each unit is closer to } \\
\text { facilities. }\end{array}$ & $\begin{array}{l}\text { Little WIP on } \\
\text { neat site. }\end{array}$ \\
\hline
\end{tabular}

\section{Conclusions}

Aiming at the production characteristics of the workshop and existing problems in the original layout, this paper studies the layout optimization of an electronic products workshop. First, the idea of combining cell manufacturing mode with SLP method is proposed, and various product types in the workshop are divided into 21 categories. On this basis, logistic relations, non-logistic relations are calculated and analyzed by using systematic layout planning (SLP) method to achieve the operating position relations graph of operation units. Finally, based on operating position relations graph, the original workshop layout is improved, with a comparison of the workshop logistics and the logistics indices before and after improvement. Application results show that the annual handling amount and the annual total handling distances of the material flow after improvement reduced significantly than before improvement. The logistics analysis and the workshop layout optimization method proposed in this paper has high application value for multi-variety and small batch production of electronic products workshop.

\section{References}

[1] Schlick M. C. (Ed.),Industrial Engineering and Ergonomics: Visions, Concepts, Methods and Tools. Springer, 2009.

[2] Salvendy G. (Ed.), Handbook of Industrial Engineering (3rd Edition), New York, Wiley, 2001

[3] Jingsheng L., Aimin W., Chengtong T., Production planning in virtual cell of reconfiguration manufacturing system using genetic algorithm, Int J Adv Manuf Technol (2014) 74:47-64

[4]Ramazan Ş., A simulated annealing algorithm for solving the bi-objective facility layout problem, Expert Systems with Applications, Volume 38, Issue 4, 2011, 4460-4465

[5] Hadi-Vencheh,A., Mohamadghasemi, A., An integrated AHP-NLP methodology for facility layout design, Journal of Manufacturing Systems, Volume 32, Issue 1, January 2013, 40-45

[6] D.P. Van Donk, G. Gaalman. Food Safety and Hygiene: Systematic Layout Planning of Food Processes, Chemical Engineering Research and Design, Volume 82, Issue 11, November 2004, Pages 1485-1493

[7] Gordana C., Analyze of the planning, layout and logistics in garment manufacturing Management of Technology Systems in Garment Industry, 2011, Pages 106-152

[8] Mohammad M., Kamran F., A novel approach for considering layout problem in cellular manufacturing systems with alternative processing routingsand subcontracting approach. Applied Mathematical Modelling. 38 (2014) 3624 - 3640

[9] Christian B., Hanno V, et al., Improving Factory Planning by Analyzing Process Dependencies, Procedia CIRP, Volume 17, 2014, Pages 38-43 
[10]Agarwal A., Sarkis J. Evaluating Functional and Cellular Manufacturing Systems: AModel and Case Analysis. International Journal of Manufacturing Technology and Management, 2001, $3(6), 528-549$

[11] Shahrukh A. Irani. Handbook of Cellular Manufacturing Systems, New York, Wiley, 2007 